\title{
Effects of Teachers' Effectiveness on Students' Academic Performance in Public Secondary Schools; Delta State - Nigeria
}

\author{
Agharuwhe A. Akiri \\ Department of Educational Administration and Policy Studies, \\ Delta State University, Abraka Delta State, Nigeria \\ E-mail: agtakiri@yahoo.com
}

\author{
Doi:10.5901/jesr.2013.v3n3p105
}

\begin{abstract}
This study determined the effects of teachers' classroom effectiveness on student's academic performance in public secondary schools in Delta State, Nigeria. The design was descriptive in nature and it involved 300 teachers, Academic performance records of 50 students per teacher, which is 1690 students' scores were also used. Questionnaires and rating scale were used to collect data for the study. Three hypotheses were tested at the 0.05 level of significance using correlation, $t$-test, and single factor analysis of variance. The results showed that effective teachers produced better performing students. However, the observed differences in students' performance were statistically not significant. This could be due to the influence of student and school environment related factors which were not included in this study. It was concluded that teachers' effectiveness is not the only determinant of students' academic achievement.
\end{abstract}

Keywords: Academic performance, learning, professional development, secondary school, student achievement, teachers effectiveness, teachers experience, teachers inexperience, teachers qualification, teaching.

\section{Introduction}

The issue of declining academic performance of students in Nigeria secondary schools has generated much interest among stakeholders in the education sector in Delta State. The quality of education and performance of students depends on the teachers as reflected in the discharge of their duties. Over time pupils' academic performance in both internal and external examinations had been used to determine the effectiveness of teachers and teaching (Ajao, 2001). This was buttressed by Ogunsaju (2004) that the academic standard of students in all Nigerian educational institutions has fallen considerably below societal expectations.

Teachers have been known to have important influence on students' academic achievement and they also play a crucial role in educational attainment because the teacher is ultimately responsible for translating educational policies and principles into actions based on practice during interaction with the students (Afe, 2001). Both teaching and learning depend on teachers: no wonder an effective teacher has been conceptualized as one who produces desired results in the course of his duty as a teacher (Uchefuna 2001). Considering governments' huge investment in public education, its output in terms of quality of students has been observed to be unequal with government expenditure. Consequent upon the observed deterioration in the academic achievement, attitude and values of secondary school students in public secondary schools, one wonders if the high failure rates and the failure of the students especially in external examinations is not a reflection of the instructional quality in the schools. Therefore, the ineffectiveness of teachers in classroom interaction with the students could be responsible for the observed poor performance of students and the widely acclaimed fallen standard of education in Nigeria.

This study was designed to determine if teachers' classroom effectiveness has significant influence on the academic performance of students in public secondary schools in Nigeria. It was aimed at answering the question: "Does teachers' classroom effectiveness have significant influence on student's academic performance?" In answering this question, the study determined and described the relationship between teachers' effectiveness and the academic performance of students. Therefore, this study is significant because the results enabled the researcher to proffer useful suggestions to the ailing problem of poor academic performance of students. 


\section{Review of Related Literature}

Teachers' effectiveness has been accepted as a multidimensional construct since it measures a variety of different aspects of teaching such as; subject mastery, effective communication, lesson preparation and presentation (Onyeachu, 1996). The influence of teachers' teaching effectiveness on the learning outcome of students as measured by students' academic performance has been the subject of several studies (Adediwura and Tayo 2007; Adu and Olatundun 2007; Lockhead and Komenan 1988; Schacter and Thum 2004; Starr 2002). The above studies suggest that effective teaching is a significant predictor of students' academic achievement. Therefore, effective teachers should produce students of higher academic performance.

Poor academic performance of students in Nigeria has been linked to poor teachers' performance in terms of accomplishing the teaching task, negative attitude to work and poor teaching habits which have been attributed to poor motivation (Ofoegbu, 2004). It has also been observed that conditions that would make for effective teaching such as resources available to teachers, general conditions of infrastructure as well as instructional materials in public secondary schools in Nigeria are poor (Oredein, 2000). Other factors that may contribute to teachers effectiveness include; relationship between the students and the teacher; teachers' teaching experience and qualifications. The prevailing conditions would definitely show a negative or positive influence on the instructional quality in public schools, which may translate to either good or poor academic performance, attitude and values of secondary school students. ljaiye (1998) concurred that improving the quality of the teaching force in schools is the key to raising student achievement, consequently Lassa (2000) and Guya (1998) claimed that education cannot be provided by just anybody, it requires a teacher who plans and delivers the lessons or instruction in such a way that objectives can be achieved. Corroborating this, Owolabi (2007) stated that government should find all possible means to retain veteran and experienced teachers who are still willing to serve so that they can contribute their wealth of experience to improve the system.

Although teachers' strong effect would significantly influence students' academic achievement, other factors such as socio-economic background, family support, intellectual aptitude of student, personality of student, self-confidence, and precious instructional quality have been found to also influence students' examination score (Starr, 2002) either positively or negatively. To this end, (Blankstein, 1996) had stated that students' grades and test scores are not good indicators of the quality of teachers' instruction. In support of this view, a study carried out in Nigeria by Joshua and Kritsonis (2006) showed that Nigerian teachers condemn the use of student achievement scores as indicators of teachers' competence, performance or effectiveness.

Since students' academic scores are not the only predictors of teachers' effectiveness, researches have sought other fairer ways of evaluating teachers' effectiveness. Students, administrators, colleagues and the teachers' self evaluation have been used to evaluate teachers' effectiveness. Students' competence in the evaluation of the effectiveness of their teachers has been of great concern to researchers in education. However, studies have shown that students' ratings are valuable indicators of teachers' effectiveness (Barnett, Matthews and Jackson, 2003; Imhanlahini and Aguele 2006; Pozo-Munoz et al. 2000). Despite the fact that there are researches reports in support of students' rating of their teachers' effectiveness, Nuhfer (2004) and Pozo-munoz et al. (2000) warned that students rating should be one of a comprehensive evaluation system and should not be the only measure of teachers' effectiveness. Ekwesili (2006) however, opined that students' success depends on the amount of learning that takes place in the classroom. The school administrators' evaluation has also been used to evaluate teachers' effectiveness. The accuracy of school administrators' evaluation of teachers' effectiveness has also been studied. Jacob and Lefgren (2006) found a positive correlation between a principals' assessment of how effective a teacher is at raising students' achievement and that teacher's success in doing so as measured by the value- added approach. The above study suggests that administrator's rating may also be one of a comprehensive evaluation system to measure teachers' effectiveness in secondary schools.

Bangbade (2004) found that out that teachers' attribute have significant relationship with students' academic performance. Such attributes according to Bangbade (2004) include teachers' knowledge of the subject matter, communication ability, emotional stability, good human relationship and interest in the job. Rena (2000) explained that for students to perform well in any examination one of the prerequisites is that their teachers must know them and have profound knowledge of their state of physical, intellectual and psychological readiness.

In many countries, teachers' qualifications that are considered to be related to student learning have become desirable targets of teacher education reform. Some of these reforms call for the professionalization of teacher education by making it longer, upgrading it to graduate programs, and regulating it through mechanisms of licensure, certification, and promotion align with standards (Thorenson, Darling- Hammond and Berry, 2001; Darling-Hammond, Chung and Frelow (2002). 
Professional development activities can be conducted by many different organizations, in schools and out of school, on the job or on sabbatical leave. On these occasions, practicing teachers update their content knowledge and teaching skills to adjust to the introduction of new curricula, new research findings on teaching and learning, changes in the needs of students, population etc. Studies by Wenglinsky (2000) found a positive effect of professional development on students' achievement.

Studies on the effect of teacher experience on student learning have found a positive relationship between teachers' effectiveness and their years of experience. The evidence currently available suggests that inexperience teachers are less effective than more senior teachers (Rivkin, Hanushek, and Kain, 2000).

The literature reviewed indicates that effective teachers positively influence the academic achievement of students. However, students' related factors were also found to have influence either positive or negative on students' academic outcomes.

\section{Research Hypotheses}

Hence, the following research hypotheses were formulated and tested.

1. There is no significant relationship between teachers' effectiveness and students' academic performance.

2. There is no significant difference in the academic performance of students taught by highly qualified, moderately qualified and less qualified teachers.

3. There is no significant difference in the academic performance of students taught by experienced and inexperienced teachers.

\section{Purpose of the Study}

The purpose of the study is to investigate the effects of teachers' effectiveness on students' academic performance in public secondary schools in Delta State. Also, to find out the effects of teachers' qualification and experience on students' academic performance.

\section{Methods and Procedure}

This study was a descriptive survey that employed an ex-post-facto design that involved the determination and description of the influence of teachers' effectiveness on students' academic achievement. It investigated the facts as they involve how teachers qualifications and experience affect the training that involve teachers' effectiveness on students' academic performance in schools.

\section{Sample and Sampling Procedure}

The study was targeted at all teachers and students in government owned secondary schools in Delta State of Nigeria. A sample of three hundred and fifty (350) teachers in public secondary schools of the State were used for the study, at the time of this study, by stratified random sampling technique. The teachers were drawn from forty-two (42) public secondary schools in the State as at 2006/2007 school year. Stratification ensured an even distribution of subjects used in the study. Ten students were also randomly drawn from each participating teachers and students for the study.

\subsection{Instrumentation}

The instruments utilized for the study was a questionnaires and one rating scale. The questionnaires tagged Teacher Effectiveness Questionnaire (TEQ) was designed for school administrators and students to evaluate the teaching effectiveness of the sampled teachers in each school. The questionnaires sought information on the teachers' effectiveness in the areas of subject mastery, lesson preparation and presentation, punctuality and attendance in class, clear communication, adequate use of instructional materials, creativity and resourcefulness, adequacy of teachers' evaluation of students' academic work and teachers' concern for students. The questionnaires contained twenty-two structured items whose scores were graded in a four-point modified Likert's scale with 4 being very high and 1 being very low in the attribute in question. The instruments were face validated, then construct validated by factor analysis using Statistical Package for Social Sciences (SPSS) version 12.0. Cronbach's coefficient alpha values of 0.98 and 0.79 were 
obtained for the Teacher Effectiveness Questionnaires. The rating scale, tagged Student Academic Performance Rating Scale (SAPRS) was designed to enable the researcher evaluate the academic performance of students taught by the teachers from 2002/2003 to 2004/2005 school years. The raw scores of fifty randomly selected students taught by the participant teachers were used to measure the academic achievement of each participating teachers' student. The researcher and research assistants obtained the students' raw scores form the academic records in the respective schools. The students' scores were scaled from 1 to 4 using the quartile ranks. Scores in the first quartile corresponded to one point while scores in the fourth quartile corresponded to four points in a four-point Likert's scale.

\section{Data Collection}

The questionnaires were administered to the respondents on the spot. A total of three hundred and fifty (350) usable questionnaires were returned administrators while a total of nine hundred and sixty (960) from students, a response rate of $85 \%$. These data were obtained by the researcher and research assistants who also obtained the scores of these students directly from the academic records in the sampled schools.

\section{Data Analysis}

The analyses used data from surveys and administrative records. The measures of teachers' effectiveness ranged from 1 and 4, with higher values corresponding to a greater quantity of a particular attribute. The students' scores were also scaled from 1 and 4 using the percentile ranks. Scores in the first percentile corresponded to one point, while scores in the fourth percentile corresponded to four points on a four point Likert's scale. The analysis centered on testing the three null hypotheses to determine and describe the influence of teachers' effectiveness on students' academic performance. Pearson Product Moment Correlation; t-Test and one way ANOVA were used to test the hypotheses. All hypotheses were tested at 0.05 level of significance or $95 \%$ certainty of prediction.

\section{Results}

\subsection{Hypotheses 1}

There is no significant relationship between teachers' effectiveness and students' academic performance.

A total number of 350 questionnaires each for teachers and students were used for this analysis. The Pearson product moment correlation was used to test this hypothesis. The result is displayed in tables 1 using the formula:-

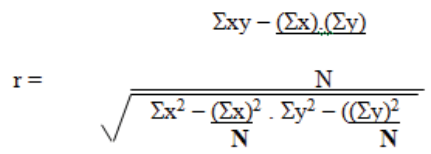

Table 1: Summary of Pearson Product Moment Correlation between teacher effectiveness and student academic performance in public secondary schools in Delta State

\begin{tabular}{|c|c|c|c|c|c|c|c|c|}
\hline Var & & Number & $\sum x$ & $\Sigma x^{2} y^{2}$ & $\sum x y$ & $\mathrm{R}$ & Crit. r. & Rmk \\
\hline TER & $x$ & 350 & 2450 & 1002900 & \multirow[b]{2}{*}{1922800} & \multirow[b]{2}{*}{0.31} & \multirow[b]{2}{*}{0.95} & \multirow{2}{*}{$\begin{array}{l}\mathrm{H}_{\mathrm{O}_{1} \mathrm{Not}} \\
\text { Sig. }\end{array}$} \\
\hline SAPR & $y$ & 960 & 3980 & 960200 & & & & \\
\hline
\end{tabular}

$P<0.05$ level of significance (One tail)

Source: Analysis of field data, 2007

Table 1 shows that there is a positive correlation between teachers' effectiveness and students' academic performance. Consequently, the hypothesis was retained. There is no significant relationship between the efficiency of teachers and students academic performance in public Secondary schools in Delta State- Nigeria.

Table 2 shows that teachers' effectiveness contributed only $0.7 \%$ (R squared $=0.007 ; p<0.05$ ) to the variance in student academic performance. This contribution is not significant. Therefore, the null hypothesis was retained and it 
was concluded that there is no significant relationship between teachers' effectiveness and students' academic performance in public secondary schools in Delta State Nigeria. It is noteworthy that $99.3 \%$ of the variance in students' academic achievement in this study is attributed to non-teacher effects.

\subsection{Hypothesis 2}

There is no significant difference in the academic performance of students taught by highly qualified (M.Ed), moderately qualified (B.Ed) and less qualified teachers (NCE and others)

Table 2: Single factor analysis of variance of teachers' qualifications and students' academic performance rating in public secondary schools in Delta State Nigeria.

\begin{tabular}{|c|c|c|c|c|c|c|c|c|}
\hline \multicolumn{9}{|c|}{ Summary } \\
\hline Groups & \multicolumn{2}{|c|}{ Count } & & \multicolumn{2}{|c|}{ Sum } & & Average & Variance \\
\hline SAPR & \multicolumn{2}{|c|}{979} & & \multicolumn{2}{|c|}{56720} & & 57.9366701 & 97.9694004 \\
\hline TER & \multicolumn{2}{|c|}{979} & & \multicolumn{2}{|c|}{78708} & & 80.3963228 & 64.2783505 \\
\hline \multicolumn{9}{|c|}{ Anova } \\
\hline \multicolumn{2}{|c|}{ Source of variance } & & & df & MS & $F$ & P-value & F crit \\
\hline \multicolumn{2}{|c|}{ Between Groups } & & & 1 & 246921.4 & 3043.76 & $<0.051$ & 3.85 \\
\hline \multicolumn{2}{|c|}{ Within Groups } & & & 81.12 & 977 & & & \\
\hline \multicolumn{2}{|c|}{ Total } & & & 82.12 & 978 & & & \\
\hline
\end{tabular}

Source: Analysis of field data, 2007

The table shows that F-calculated $(F=3043.76 ; p<0.051)$ is higher than $F$-critical $(3.85)$. Therefore, the null hypothesis was refuted and it was concluded that there is a very significant difference in the academic performance of students taught by the various qualifications identified in the study. The teachers' effectiveness rating is significantly higher than the students' academic performance of students in Delta State Public secondary schools.

Hypothesis 3

There is no significant difference in the academic performance of students taught by Inexperienced and experienced teachers.

The t-test analysis was used and the result is shown in table 5.

$$
\mathrm{t}=\sqrt{\frac{\mathrm{N}_{1}-1\left(\mathrm{~S}_{1}\right)+\mathrm{N}_{2}-1\left(\mathrm{~S}_{2}\right)}{\mathrm{N}_{1}+\mathrm{N}_{2}-2}} \cdot 1 / \mathrm{N}_{1}+1 / \mathrm{N}_{2}
$$

Table 3: $t$ - test Analysis of variance of Students taught by less experienced and experienced Teachers in Public Secondary Schools in Delta State, Nigeria

\begin{tabular}{|c|c|c|c|c|c|c|c|}
\hline \multicolumn{8}{|c|}{ Summary } \\
\hline Groups & $\mathrm{N}$ & Sum & Average & Variance & $P$ & Crit. t. & Remark \\
\hline $\begin{array}{c}\text { In- experienced } \\
\text { Teachers.(1-5yrs) }\end{array}$ & 350 & 19747 & 56.42 & 133.13 & & & \\
\hline $\begin{array}{c}\text { Experienced } \\
\text { Teachers. }(5-20 \mathrm{yrs})\end{array}$ & 350 & 20321 & 58.06 & 95.61 & 1.074 & 000 & $\mathrm{Ho}_{3}$ rejected \\
\hline
\end{tabular}

$p \geq 0.05$ level of significance

Source: Analysis of data from the field.

The analysis of this hypothesis show that students perform better when taught by experienced teachers more than less experienced teachers in public secondary schools in Delta State, Nigeria. 


\section{Discussion}

The study found that teachers who were rated as ineffective considering the variables for the study actually produced students of lower academic ability. However, the difference found in the mean performance of students was statistically not significant. This agrees with the view which indicates that effective teachers produced high performing students. The reported level of students' performance may not be a good reflection of the quality of the schools. It may be more of the function of the quality of students and the environment of learning in public secondary schools. The students come into the school with low intellectual ability and poor attitude to academic work. Therefore, the student's factors may be more responsible for the reported level of student's performance in these schools than teachers' effectiveness. A possible consequence of this is that students' and school environment factors may have marked the actual influence of teachers' effectiveness.

The results of this study is in agreement with the statement of Blankstein (1996) that students grades and test scores do not reflect the quality of instruction because teachers' input is not the only factor that influences student academic performance in schools. Starr (2002) had identified peer influence, race, ethnicity, gender, motivating income, intellectual aptitude of the students, personality of students, self confidence, and previous instructional quality received by students, house hold environment, and parental education as student's related factors that influence the academic performance of students. However, the study is not consistent with the studies of Schacter and Thum (2004) and Starr (2002), which found a high correlation coefficient between teachers' effectiveness and students' academic performance.

\section{Conclusion}

Teachers' classroom effectiveness has been found to have only a minimal influence on the academic performance of students in public secondary schools in Delta State, Nigeria. This is due to the fact that teacher's effort is not the sole determinant of students' academic outcome. Students related factors such as intelligence, parental education, socioeconomic status, and personalities which vary over wide margins in the study area may have significant effect on the academic performance of students in public secondary schools. This may also influence significantly on the academic performance of students and consequently may be responsible for the observed low performance of students when compared with the effectiveness of their teachers.

\section{Recommendation}

Government should attempt to improve the attitude of students to academic work by providing libraries and laboratories for science practical to enable learning experience of the students become more meaningful and at the same time interesting. There is the need to build more classrooms and make more adequate provision for seats especially in urban schools to ease the problem of overcrowded classrooms and poor sitting arrangement that presently make teaching and learning difficult in public secondary schools. This will further improve effective classrooms control for better teaching and learning to take place in the schools.

School principals should endeavour to make necessary instructional materials available to teachers when needed. The staff rooms should also be conducive for teachers to adequately prepare their lessons. This can motivate teachers to do better in their interaction with students.

Teachers should be encouraged to embark on regular professional development.

Finally, teachers should bring their wealth of experience in teaching to the level of the students' aptitude to make classroom interactions more interesting so as to arouse the interest of the students to academic excellence. This would assist in solving the problem of poor academic performance of public secondary school students and improving widely the acclaimed fallen standard of education in Delta State, Nigeria.

\section{References}

Adediwura AA \& Tayo B 2007. "Perception of Teachers' Knowledge Attitude and Teaching Skills as predictor of Academic Performance in Nigeria Secondary Schools". Educational Research and Review, 2(7): 165-171

Adu EO \& Olatunde SO 2007. "Teachers' perception of Teaching as Correlate of Students' Academic Performance in Oyo state Nigeria". Essay in Education, 20:57-63.

Afe JO 2001. "Reflections on Becoming a Teacher and Challenges of Teacher Education". Inaugural Lecture Series. 64. University of Benin, Benin City: Nigeria. 
Ajao W 2001."Cadbury is Determined to move Education Forward". Vanguard, December 27 2001, P. 16.

Bangbade JO 2004. "Effects of subject matter knowledge in the teaching and learning of Biology and Physic". Teaching and Teacher Education: 109-102.

Barnett CW Matthews HW \& Jackson RA 2003. "Comparison Between Student rating and Faculty Self-rating of Instructional Effectiveness". American Journal of Pharmaceutical Education, 67(4): 1-6

Blanksttein AM 1996. "Why TCM can't work - and a school where it did". The Education Digest. 62(1): 27-30.

Dunkin MJ 1997. "Assessing Teachers Effectiveness"Issues in Educational Research, 7(1), 37-51.

Imhanlahimi EO \& Aguele LI 2006. "Comparing Three Instrument for Assessing Biology Teachers' Effectiveness in the Instructional process in Edo state Nigeria". Journal of Social Sciences. 13(1):67-70.

Jacob B \& Lefgren L 2006. When Principals rate teachers. Education Next. Hoover Institution. Retrieved on March 52006 from http:www.educationnext.org/2006/58.html.

Joshua MT \& Joshua Kritsonis AW 2006. "Use of students' Achievement scores as Basis for Assessing Teachers' Instruction Effectiveness: Issues and Research Results". National forum of Teachers Education Journal. 17(3): 1-3.

Lockhead EM \& Komenan A 1988. "School Effective and Students' achievement in Nigeria and Swizz-Land". Working paper Series 71, Washington DC: World Bank.

Maduka N 2000. "The Relationship Between Service Condition of Teachers and their Effectiveness in Secondary Schools in Abia State". MEd Dissertation. Port Harcourt: University of Port Harcourt, Nigeria.

Nuhfer EB 2004. Fractals and the value of student evaluators. Centre for Teaching and Learning, Idaho State University, Retrieved October 32005 from www.isu.edu/facultydev/extras/meaningevalsfract files/meaningevalsfract.htm.

Ofoegbu FI 2004. Teacher Motivation: a factor for classroom Effectiveness and school Improvement in Nigeria. Gale Group. Retrieved August 15 2005, from htp:www.findarticles.com.

Ogunsaju S 2004. A guide to school effectiveness in Nigeria. Ibadan. Laville Publications.

Onyeachu A 1996. "Relationship Between Working Conditions and Teacher Effectiveness in Secondary Schools in Abia Educational Zone of Abia State". MEd dissertation. Port Harcourt: University of Port Harcourt, Nigeria.

Oredein AO 2000. "Leadership Characteristics and Personnel Constraints as Factors of School and Industrial Effectiveness". Ph.D. thesis, unpublished, Ibadan: University of Ibadan, Nigeria.

Rena U 2000. "Who will teach? A case study of Teacher Education Reform". Caddo Gap Press. Califonia: pp 318.

Rivkin SG Hanushek EA \& Kain JF 2000. "Teachers, schools and academic achievement(working paper 6691 revised)". Cambridge,MA: National Bureau of Economic Research.

Schacter J \& Thum YM 2004. "Paying for High and Low Quality Teaching". Economics of Education Review, 23: 411-430.

Starr L 2002. "Measuring the Effective Teaching Education World". Retrieved October 16 2005, from www.education-world.com/a issues.shtml.

Thoremson A Darling-Hammond L Berry B 2001. "Does teacher certification matter? Evaluating the evidence". Educational Evaluation and Policy Analysis: 23(1)57-77.

Uchefuna, M. C. 2001. "A study of clinical Supervision and Teachers, effectiveness in Umuahia and Abia Educational Zones of Abia State". MEd Dissertation. Port Harcourt, University of Port Harcourt, Nigeria.

Wenglinsky H 2000. "How teaching matters; Bringing the classroom back into discussion of teacher quality policy". Information Center Report October, Educational Testing Services. 
